DOI 10. 18307/2021. 0212

(C) 2021 by Journal of Lake Sciences

\title{
调水引流工程对平原河网水动力调控的效果”
}

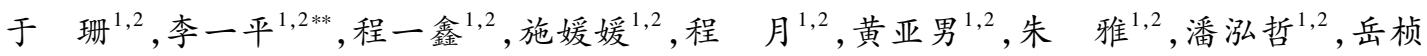 \\ 铻 $^{1,2}$, 郑 可 ${ }^{1,2}$ \\ ( 1 : 河海大学环境学院,南京 210098) \\ (2:河海大学浅水湖泊综合治理与资源开发教育部重点实验室,南京 210098)
}

\begin{abstract}
摘 要: 平原河网多存在河道流动性不强, 河道生态流速难以保障的问题, 以典型平原河网地区一一宁波市海曙区为例, 开展野外原型同步监测, 以河道分流比、换水率及槽蓄量为研究对象, 系统分析引调水工程对河网水动力的调控效果. 结 果表明:平原河网水动力改善效果与引排水口分布、引水流量密切相关, 为保证河网区水体交换良好, 引排水口的连线应 尽可能贯通整个区域; 平原河网换水率在空间分布上具有很强的异质性 (4 种调水方案下河道换水率极差, 最大为 $190 \%$, 最小为 $75 \%$ ), 引调水工程能够改善分流能力大的支汉的水动力特征, 对分流能力小的支汉及断头河的水动力状况帮助 不大; 河网换水率提高、槽蓄量变化率减小是区域水动力改善的必要条件, 海曙区较小的槽蓄量变化率为 $0.2 \%$ 左右. 本研 究分析了河网区的河道输水能力以及换水率, 对优化河网概化密度以减小模拟偏差有参考意义, 为进一步探究平原河网 水动力改善促进水环境质量提升提供基础,利于特殊水动力特征河道治理和区域水环境管控.
\end{abstract}

关键词: 平原河网;水动力; 换水率;分流比;槽蓄量

\section{The impacts of water diversion on hydrodynamic regulation of plain river network *}

Yu Shan ${ }^{1,2}$, Li Yiping ${ }^{1,2 *}$, Cheng Yixin ${ }^{1,2}$, Shi Yuanyuan ${ }^{1,2}$, Cheng Yue ${ }^{1,2}$, Huang Yanan ${ }^{1,2}$, Zhu Ya ${ }^{1,2}$, Pan Hongzhe $^{1,2}$, Yue Zhenwu ${ }^{1,2}$ \& Zheng $\mathrm{Ke}^{1,2}$

(1: College of Environment, Hohai University, Nanjing 210098, P.R.China)

(2: Key Laboratory of Integrated Regulation and Resource Development on Shallow Lakes, Ministry of Education, Hohai University, Nanjing 210098, P.R.China)

Abstract: In the plain river network area, the mobility of rivers is usually poor and the ecological flow velocity of rivers is difficult
to be guaranteed. Taking Haishu District of Ningbo City, a typical plain river network area, as an example, a field prototype syn-
chronous monitoring experiment was carried out. The effect of water diversion on hydrodynamic regulation was systematically studied
with the river diversion ratio, water exchange rate and storage capacity as the research objects. The results showed that: The hydro-
dynamic improvement effect of plain river network was closely related to the position of water inlets and outlets and water diversion
flow. To ensure a good water exchange rate, the connection of water inlets and outlets should run through the whole area as far as
possible. The water exchange rate of plain river network area had strong heterogeneity in spatial distribution ( under the four
schemes, the maximum range of water exchange rate was $190 \%$ and the minimum was $75 \%$ ). The water diversion project could im-
prove the hydrodynamic characteristics of the branches with large diversion capacity, but it was not helpful for the branches with
small diversion capacity and truncated creek. The improvement of regional hydrodynamic needed to increase the water exchange rate
and decrease the change rate of storage capacity, the smaller change rate of storage capacity in Haishu district was about $0.2 \%$. The
study analyzed the water conveyance capacity and water exchange rate, which has reference value for optimizing the generalized
density of river network to reduce the simulation deviation and provides a basis for exploring the improvement of water dynamics in

* 2020-05-17 收稿;2020-07-13 收修改稿.

国家水体污染控制与治理科技重大专项 (2017ZX07204003)、中央高校建设世界一流大学 (学科) 和特色发展引导 专项资金联合资助.

** 通信作者;E-mail : liyiping@ hhu.edu.cn. 
plain river network and promoting the water environment quality. It will also be conducive to river regulation with special hydrodynamic characteristics and regional water environment control.

Keywords: Plain river network; hydrodynamic; water exchange rate; diversion ratio; storage capacity

随着中国社会经济的快速发展和城市化的不断加快, 河流形态结构发生了改变, 由此带来水环境恶化、 河网调蓄能力下降等一系列问题 ${ }^{[1]}$. 水动力是河湖生态系统的重要基础变量 ${ }^{[2]}$, 为改善和维护区域水环境, 增强水动力条件成为治理水环境的措施之一,其中调水引流是较为常见且重要的一种手段. 东京 1964 年从 利根川和荒川引人清水改善隅田川水质从而开启了引清调水的先河 ${ }^{[3]}$, 此外如德国鲁尔河 ${ }^{[4]}$ 、俄罗斯莫斯 科河 ${ }^{[3]}$ 、国内的“引江济淮” ${ }^{[5]}$ 、引江济太” ${ }^{[6]}$ 工程等都得到了很好的水环境改善效果,但相关研究多集中 在大型河流和湖泊之中. 近几年调水调控工作在平原河网地区逐渐开展, 贾海峰等 ${ }^{[7]}$ 通过苏州市角直镇的 水动力一水质模型, 为区域提出水系结构优化和水利调度强化的改善方案, 宋利祥等 ${ }^{[8]}$ 通过二维水流一输送 耦合模型, 模拟水闸调度影响下的感潮河网水流运动及污染物运输过程, 田传冲等 ${ }^{[9]}$ 基于温州市主城区河 网水动力模型, 计算区域达到目标流速所需的引水量, 并指出水环境改善程度与调水量及换水周期密切相 关. 现有研究通常以数值模拟为研究手段, 对河网水体交换的分析主要集中在交换时间方面, 鉴于平原河网 区多为网状分流河道, 河道具有分汉和再汇合的复杂形态, 流量与流向变化不规则, 相关研究缺少基于野外 原型同步监测, 掌握河网及调水线路上的河道分流比、水量空间分布情况, 系统探究调水对河网区水动力的 影响.

鄞东南平原属典型的平原河网地区, 区内河网密布, 水系发达, 河流流速缓慢且流向多变, 污染物难以 扩散、降解, 因此本文以鄞东南平原河网区的宁波市海曙区为例开展研究具有代表性. 近年来海曙区河网结 构及连通性发生改变, 河道自净能力减弱, 水环境形势日趋严峻, 因此增强水力流动性成为提高河网自净能 力的保障, 亟需将野外原型同步监测与实际调水方案密切结合以掌握河网区主要河道流量的变化情况, 并 以河道分流比、换水率为水动力条件指标, 调水总量为经济效益指标, 槽蓄量变化率为约束条件, 系统分析 调水引流工程对河网水动力的改善效果. 以期为输水工程方案的实施管理提供科学依据, 并为数值模拟提 供数据支撑, 推进平原河网水动力改善促进水环境质量提升的进一步探究.

\section{1 研究区域及方法}

\section{1 研究区域概况}

宁波市地处我国海岸线中段, 长江三角洲南翼, 海曙区 ( $29^{\circ} 54^{\prime} 27^{\prime \prime} \sim 29^{\circ} 49^{\prime} 26^{\prime \prime} \mathrm{N}, 120^{\circ} 29^{\prime} 30^{\prime \prime} \sim 120^{\circ} 33^{\prime} 35^{\prime \prime} \mathrm{E}$ ) 位于宁波市区中心区域,东临奉化江, 北濒余姚江, 西南与鄞州区接壤. 宁波城区内河水系受余姚江、奉化江 和角江三江分隔, 余姚江、奉化江在市区“三江口” 汇成甬江, 流向东北,经招宝山人东海. 海曙区河网 (图 1) 位于三江口西侧, 河网水面率 $5.1 \%$. 内河补充水源主要来自于余姚江, 余姚江现状配水利用高桥 $\left(6.8 \mathrm{~m}^{3} / \mathrm{s}\right)$ 、 黄家河 $\left(1 \mathrm{~m}^{3} / \mathrm{s}\right)$ 、屠家沿 $\left(1.5 \mathrm{~m}^{3} / \mathrm{s}\right)$ 原站引水人平原, 区域内共有 3 座沿江侯潮排水闸. 海曙区地处流域末 端, 受上游来水影响较大, 同时内河人江闸门经常性关闭, 河流基本凝滞, 河网调蓄能力差, 水质也受到极大 影响, 对《2015 年宁波市水资源公报》分析可知,参评的 35 个河网水质监测断面中, $62.8 \%$ 的水体呈 $\mathrm{V}$ 类及 劣 $\mathrm{V}$ 类, 超标项目主要为总磷、氨氮、高锰酸盐指数.

\section{2 研究方法}

1.2.1 监测方案 为了解调水期间河网及调水线路上的河道分流比、水量空间分布情况, 本研究于 2016 年 7 月 20-23 日采用 LS25-3A 型旋桨式流速仪及水位计对海曙区引余姚江水改善水动力进行野外原型同步监 测, 监测断面 35 个, 监测因子为流向、流速、水位. 根据现有闸站情况制定 4 种调水方案如表 1 , 方案 1 和方 案 2 分别为屠家沿、黄家河翻水站现状联合引水和两翻水站与高桥原站现状联合引水的调水工况; 方案 3 仍 采用方案 2 的引排水口并增加两翻水站引水时长; 方案 4 在方案 2 的基础上, 新增两个沿江闸排水口. 其中 引水㬌站引水期间的监测频率均为 $2 \mathrm{~h}$ /次, 沿江闸排水期间的监测频率为 $0.5 \mathrm{~h} /$ 次.

1.2.2 河道流量计算 采用流速面积法测流速, 根据垂线上的流速分布模型 (图 2) 简化垂线上的测点 ${ }^{[10]}$, 本 次监测所有河流流速较小且水深 $<2 \mathrm{~m}$, 因此采用一点法和二点法. 计算过程如下: 


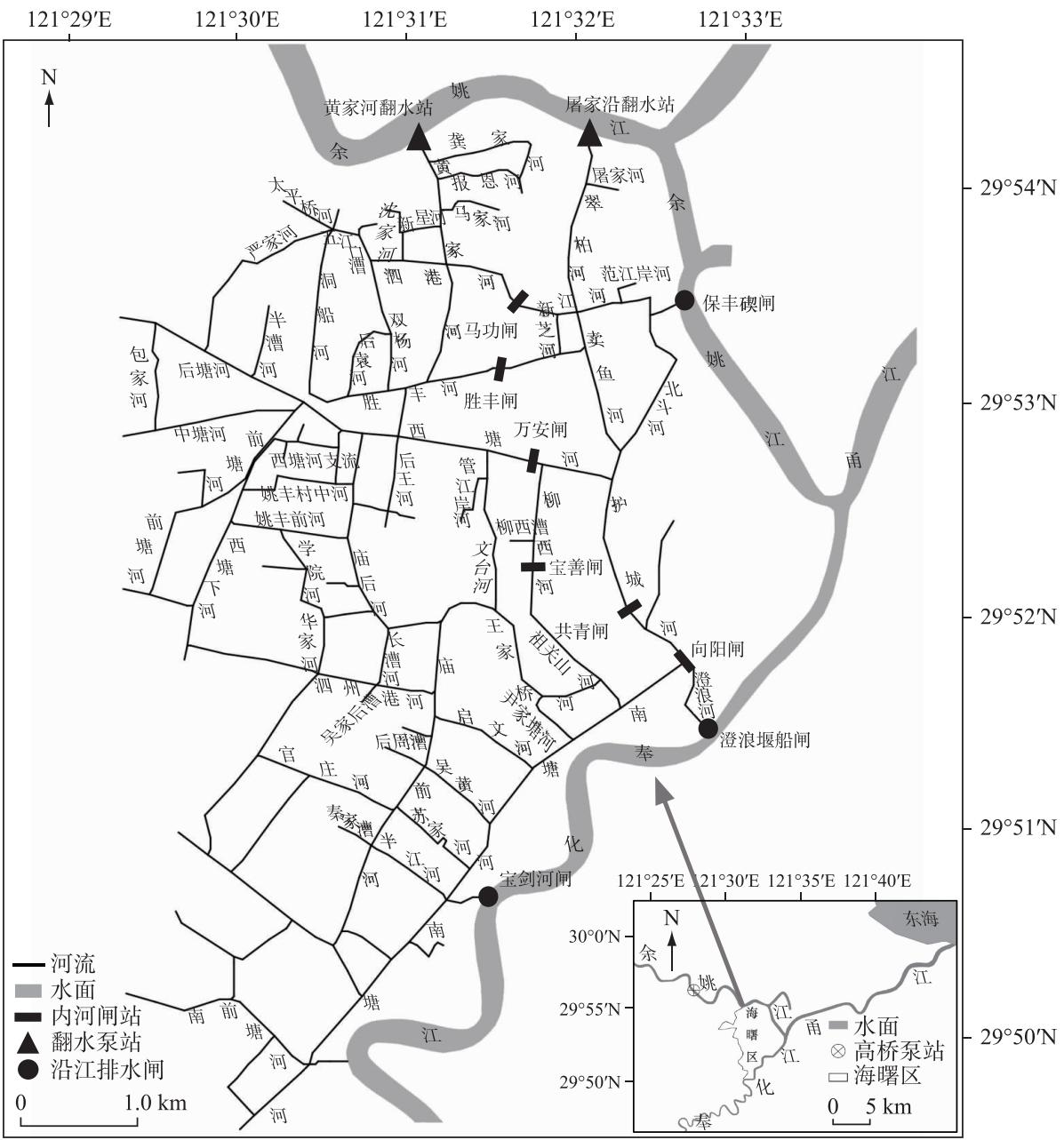

图 1 研究区示意图

（1. 图中灰色箭头代表河流流向;2. 高桥泉站位于海曙区范围外, 该原站引水对海曙区的贡献水量以西部河道来水体现)

Fig. 1 Location of the study area

表 1 海曙区调水方案”

Tab.1 Schemes of water diversion in Haishu district

\begin{tabular}{|c|c|c|c|c|c|c|}
\hline \multirow{2}{*}{ 方案- } & \multicolumn{3}{|c|}{ 引水䈋站 } & \multicolumn{3}{|c|}{ 沿江闸 } \\
\hline & 屠家沿 $(1.5$ m³/s) & 黄家河 $\left(1 \mathrm{~m}^{3} / \mathrm{s}\right)$ & 高桥 $\left(6.8 \mathrm{~m}^{3} / \mathrm{s}\right)$ & 保丰碶闸 & 澄浪堰船闸 & 宝剑河闸 \\
\hline 1 & 开 $(9: 00-17: 00)$ & 开 $(9: 00-17: 00)$ & 关 & 关 & 关 & 关 \\
\hline 2 & 开 $(9: 00-17: 00)$ & 开(9:00-17:00) & 开 $(9: 00-17: 00)$ & 关 & 关 & 关 \\
\hline 3 & 开 $(9: 00$ 一次日 9:00) & 开 $(9: 00$ 一次日 9:00) & 开 $(9: 00-17: 00)$ & 关 & 关 & 关 \\
\hline 4 & 开 $(9: 00-17: 00)$ & 开 $(9: 00-17: 00)$ & 开 $(9: 00-17: 00)$ & 开 $(14: 00-17: 00)$ & 开 $(14: 00-17: 00)$ & 关 \\
\hline
\end{tabular}

* 方案 4 中保丰碶闸在 16:00 点之前三孔全开,之后转为两孔; 所有方案中内河闸均开启.

1 ) 垂线平均流速: 垂线 (测流线) 处的水深 $<1.5 \mathrm{~m}$ 时, 采用一点法; 水深为 $1.5 \sim 2.0 \mathrm{~m}$ 时, 采用二点法. 计 


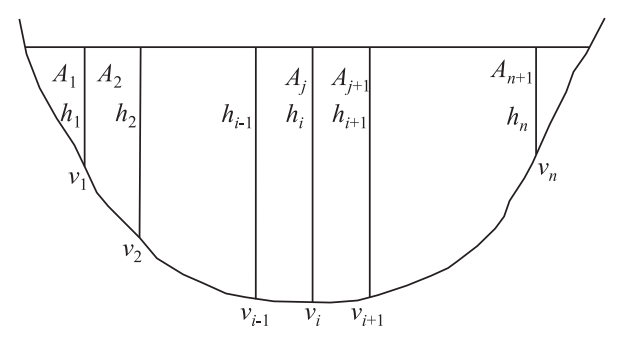

图 2 断面垂线分布

Fig.2 Vertical distribution of the sections

算公式 ${ }^{[11]}$ 为:

一点法:

$$
v_{\mathrm{m}}=v_{0.6}
$$

二点法：

$$
v_{\mathrm{m}}=0.5\left(v_{0.2}+v_{0.8}\right)
$$

式中, $v_{m}$ 为垂线平均流速 $(\mathrm{m} / \mathrm{s}), v_{0.6} 、 v_{0.2} 、 v_{0.8}$ 分别为相对水深 $0.6 、 0.2 、 0.8$ 处的测点流速 $(\mathrm{m} / \mathrm{s})$.

2) 部分面积: 部分面积, 即以测流线为分界, 分为岸边块 (距离岸边的第一条测流线与河底及水面构成) 和中间块 (两条测流线与河底及水面构成). 岸边块面积 $\left(A_{1} 、 A_{n}\right)$ 按三角形计算, 中间块面积 $\left(A_{2} \sim A_{n-1}\right)$ 按梯 形计算.

3 ) 部分平均流量: 部分平均流量分为岸边块和中间块的平均流量,计算公式 ${ }^{[10,12]}$ 为:

$$
\begin{gathered}
v_{i}^{\prime}=\alpha \cdot v_{i} \\
v_{i}^{\prime \prime}=\frac{1}{2}\left(v_{i-1}+v_{i}\right) \\
q_{j}=v_{j} \cdot A_{j}
\end{gathered}
$$

式中, $\alpha$ 为岸边系数, 与岸边性质有关, 斜坡岸边 $\alpha=0.67 \sim 0.75$, 陡岸边 $\alpha=0.80 \sim 0.90$, 死水边 $\alpha=0.5 \sim$ $0.67^{[12]} ; v_{i}$ 为第 $i$ 条测线的平均流速 $(\mathrm{m} / \mathrm{s}) ; v_{i}^{\prime}$ 为岸边块平均流速 $(\mathrm{m} / \mathrm{s}) ; v_{i}^{\prime \prime}$ 为中间块平均流速 $(\mathrm{m} / \mathrm{s}) ; v_{j} 、 A_{j}$ 、 $q_{j}$ 分别为第 $j$ 个部分的平均流速 $(\mathrm{m} / \mathrm{s})$ 、断面面积 $\left(\mathrm{m}^{2}\right)$ 、流量 $\left(\mathrm{m}^{3} / \mathrm{s}\right)$.

4) 断面流量: 部分平均流量累加即为断面流量, 计算公式 ${ }^{[10]}$ 为:

$$
\begin{aligned}
Q & =\sum_{j=1}^{n+1} q_{j} \\
\bar{v} & =Q / A
\end{aligned}
$$

式中, $Q$ 为断面流量 $\left(\mathrm{m}^{3} / \mathrm{s}\right) ; A$ 为断面总面积 $\left(\mathrm{m}^{2}\right) ; \bar{v}$ 为断面平均流速 $(\mathrm{m} / \mathrm{s})$.

河流平均水深一般采用各垂线流速所对应的水位或平均以部分流量为权重加权平均得到 ${ }^{[13]}$.

1.2.3 河道分流比 河道分流比 $\left(Q^{*}\right)$, 即各支流过水量与干流过水量之比, 表示河汊的水量分配状况 ${ }^{[14-15]}$. 计算公式 ${ }^{[14]}$ 为:

$$
Q^{*}=Q_{\mathrm{t}} / Q_{\mathrm{m}}
$$

式中, $Q_{\mathrm{m}}$ 为干流过水量 $\left(\mathrm{m}^{3} / \mathrm{s}\right) ; Q_{\mathrm{t}}$ 为支流过水量 $\left(\mathrm{m}^{3} / \mathrm{s}\right)$.

1.2.4 河道换水率 河道换水率 $(\gamma)$ 是指河道的过水量与存水量之比, 表示河道的水流交换效率. 换水率越 大, 说明水体流动情况越好 ${ }^{[16]}$. 计算公式为:

$$
\gamma=V_{1} / V_{0}
$$

式中, $V_{1}$ 为河道过水量 $\left(\mathrm{m}^{3}\right) ; V_{0}$ 为河道存水量 $\left(\mathrm{m}^{3}\right)$.

1.2.5 槽蓄量变化率 槽蓄量变化率 $(\varphi)$, 即河网区河道槽蓄量变化值与初始槽蓄量之比. 计算公式 ${ }^{[17]}$ 为:

$$
\varphi=\frac{\Delta S}{S_{0}}
$$




$$
\Delta V=8.64\left(\frac{I_{1}+I_{2}}{2}-\frac{O_{1}+O_{2}}{2}\right) \Delta t
$$

式中, $\Delta S$ 为河网区槽蓄量变化值 $\left(\mathrm{m}^{3}\right)$ (通过单条河道槽蓄量变化值累加得到); $S_{0}$ 为初始槽蓄量 $\left(\mathrm{m}^{3}\right) ; \Delta V$ 为单条河道槽蓄量变化值 $\left(\mathrm{m}^{3}\right) ; I_{1} 、 O_{1}$ 为计算时段初的人、出流量 $\left(\mathrm{m}^{3} / \mathrm{s}\right) ; I_{2} 、 O_{2}$ 为计算时段末的人、出流量 $\left(\mathrm{m}^{3} / \mathrm{s}\right) ; \Delta t$ 为时段 $(\mathrm{d})$.

\section{2 结果与分析}

\section{1 河道分流特性分析}

2.1 .1 河道过水量变化情况 分汉河道是平原河网区常见的河型, 其过水流量反映了河道的分流能力 ${ }^{[18]}$, 根 据公式 (1) (6) 计算得到各方案调水期间的河道过水量以及总引、排水量 (表 2 ) 并绘制河道过水流量图 (图 3). 结果表明: 翻水站现状引水时 (方案 $1 、 2$ ), 区域东北侧河道过水量为 0.2 万 3 万 $\mathrm{m}^{3}$, 高桥泵站引水 仅对西侧水系产生影响, 其中大部分河道过水量为 0.2 万 3 万 $\mathrm{m}^{3}$. 相比翻水站现状运行, 连续运行 (方案 3 ) 使区域河道过水量增加 $1 \sim 3$ 倍, 东北侧部分河道过水量达 2 万 $~ 8$ 万 $\mathrm{m}^{3}$, 西侧部分河道过水量增至 3 万 8 万 $\mathrm{m}^{3}$, 这与调水量有关, 调水量增加不仅使河道过水量增加且影响范围增大. 新增 2 个排水口时 (方案 4 ), 东北侧部分河道过水量增至 3 万 25 万 $\mathrm{m}^{3}$, 增加效果显著 ( $3 \sim 9$ 倍), 西侧河道过水量略有增加 ( $0 \sim 1$ 倍), 达 0.2 万 $~ 5$ 万 $\mathrm{m}^{3}$, 说明受引排水口位置的影响使西、北部来水主要流经东北侧河道而东排, 靠近东部 排水口的河道过水流量较大.

表 2 不同调水情况下的引、排水量

Tab.2 Water diversion and drainage under different water diversion schemes

\begin{tabular}{|c|c|c|c|c|c|}
\hline 方案 & 来水泵站 & 来水量 $/ \mathrm{m}^{3}$ & 来水总量 $/ \mathrm{m}^{3}$ & 出水河道/闸站 & 出水总量 $/ \mathrm{m}^{3}$ \\
\hline \multirow[t]{2}{*}{1} & 屠家沿 & 29861 & 49306 & 南塘河 & 43875 \\
\hline & 黄家河 & 19445 & & 其他河道 & \\
\hline \multirow[t]{3}{*}{2} & 屠家沿 & 29861 & 166924 & 南塘河 & 153867 \\
\hline & 黄家河 & 19445 & & 其他河道 & \\
\hline & 高桥 & 117618 & & - & \\
\hline \multirow[t]{3}{*}{3} & 屠家沿 & 75339 & 253729 & 南塘河 & 240620 \\
\hline & 黄家河 & 49585 & & 其他河道 & \\
\hline & 高桥 & 128805 & & - & \\
\hline \multirow[t]{4}{*}{4} & 屠家沿 & 46214 & 289644 & 保丰碶闸 & 427362 \\
\hline & 黄家河 & 36039 & & 澄浪堰闸 & \\
\hline & 高桥 & 207391 & & 南塘河 & \\
\hline & - & - & & 其他河道 & \\
\hline
\end{tabular}

2.1 .2 河道分流特性 分汉河道的分流特性常用分流比表示, 对防洪排涝、供水、保护河流水环境健康等有重 要意义 ${ }^{[19]}$. 比较各方案下河道过水量变化情况 (图 3), 方案 4 的整体水流流向趋势 (趋势 2 : 由北向南, 由西 向东) 有差异于前 3 种方案 (趋势 1 : 由北向南, 由东向西), 引起这 2 种水流流向趋势的主要原因是闸控方式 的不同,因此以河道分流比定量分析两种水流流向趋势下的河道分流特性(图 4).

1 ) 趋势 1 : 方案 3 中, $29.7 \%$ 的来水从屠家沿翻水站人内河,其中 $18.6 \%$ 与 $10.3 \%$ 的水流分别沿卖鱼河与 北斗河汇人护城河, 随后 $16.4 \%$ 与 $4.5 \%$ 的水流分别沿护城河和柳西河流人南塘河, $6.0 \%$ 的水流流人西塘河， 相比于现状引水 (方案 2), 卖鱼河、北斗河及护城河分流比增加 4\% 8\%, 增加效果明显, 柳西河与西塘河分 流比增量较小 $(1 \% \sim 3 \%) .19 .5 \%$ 的来水从黄家河翻水站人内河, 大部分水流沿黄家河流人胜丰河, 随后 $12.6 \%$ 和 $4.3 \%$ 的水流分别流人胜丰河与西塘河附近支汉, 后王河和胜丰河分流比分别增加 $5.1 \%$ 和 $1.7 \%$, 附 近支汉的蓄水量增大. 西塘河以南的支汉汇集了两翻水站的部分来水与西北部河道来水, $26.3 \%$ 的水流沿庙 前河流人南塘河,最终 $86.8 \%$ 的水流从南塘河南排.

2 ) 趋势 2 : 方案 4 中, 流经保丰碶闸的排水来自蔡江河与北斗河, 两翻水站的引水直汇人蔡江河, 其水流 

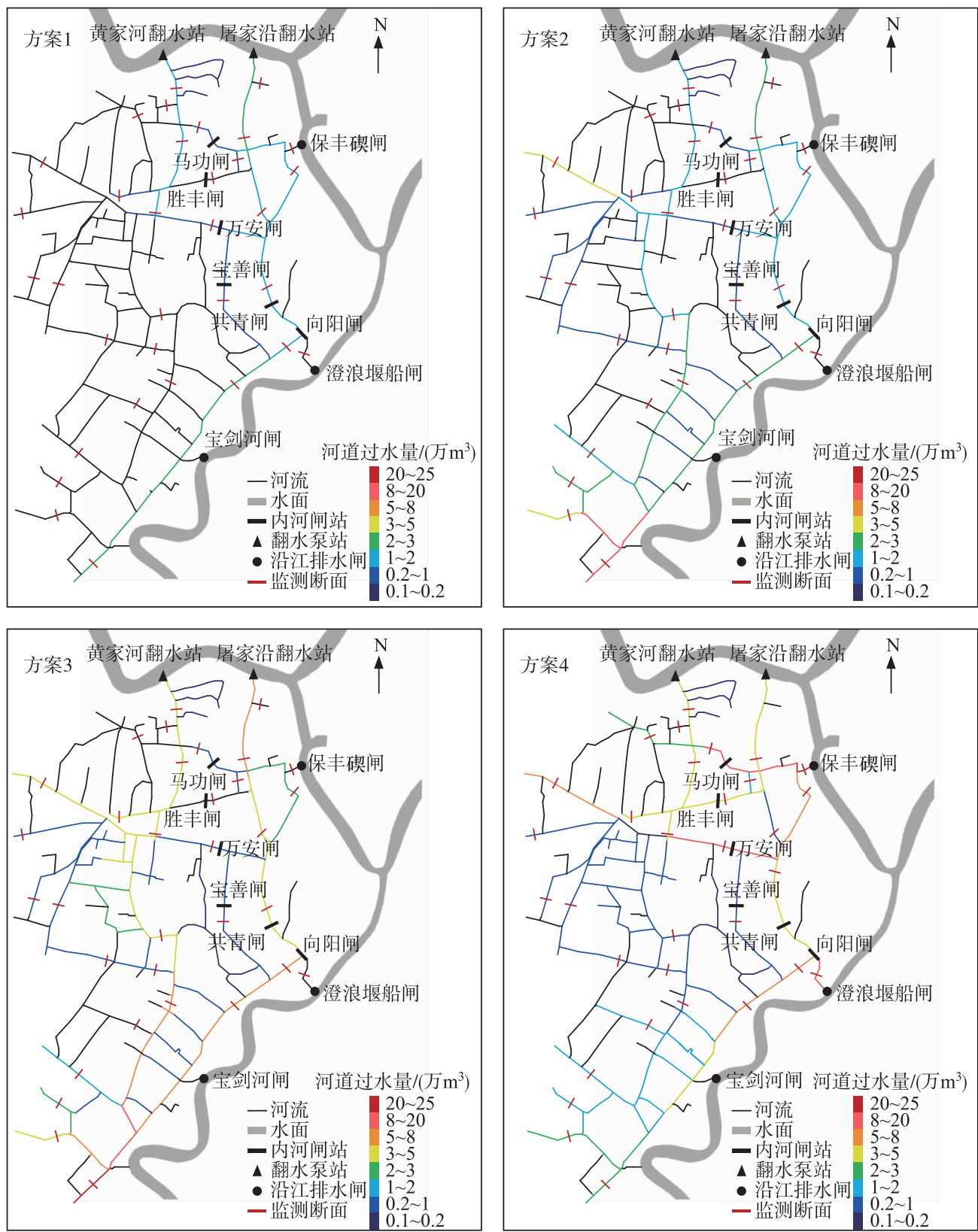

图 3 不同调水情况下的河道过水量

Fig.3 River discharge under different water diversion schemes

扩散范围较小,此外蔡江河主要汇集了流经黄家河南段 $9.5 \%$ 的水流以及流经卖鱼河 $14.4 \%$ 的水流,北斗河 主要汇集了流经西塘河 $34.5 \%$ 的部分水流, 这三股水流主要来自西北部河道来水. 相比于现状引水, 蔡江 河、北斗河及西塘河分流比增加效果显著 (分别为 $53.2 \% 、 18.5 \% 、 30.9 \%$ ). 流经澄浪堰闸的排水主要来自西 部河道来水,最终 $38 \%$ 的水流从澄浪堰闸排出, $9.1 \%$ 的水流自南塘河南排,南塘河分流比缩小, 来水大部分 从东部排出,其附近河道的分流比增大.

方案 4 中北部来水几乎全部从保丰碶闸东排,两翻水站的引水服务范围相比现状明显缩小, 说明引一排 
水口距离短的格局制约了水流扩散的态势. 另外在调水期间的不同水流流向趋势下,河道分流情况存在差 异性, 河流交汊口会随水流流向趋势的不同变成交汇口或分汊口, 从而影响河道分流比, 其中翠柏河、卖鱼 河、北斗河、护城河、黄家河为输水主干河道,区域多处存在的断头河 ${ }^{[20]}$ 分流比很小.
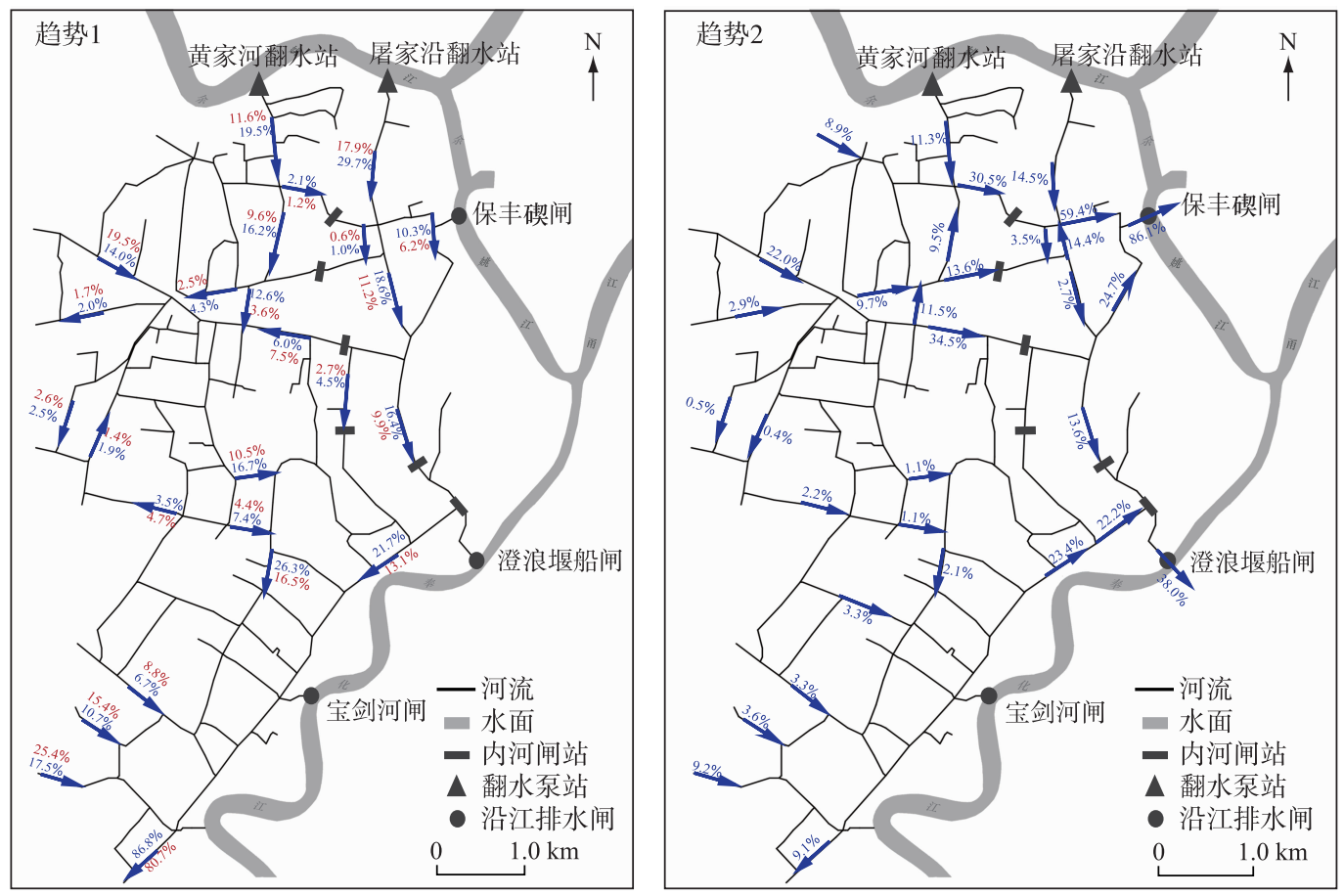

图 4 两种流向趋势下的河道分流比

（“趋势 1” 图中蓝色数字为方案 3 的河道分流比, 红色数字代表方案 2 ; “趋势 2 ” 图中蓝色数字代表方案 4)

Fig.4 Flow diversion ratio under two flow trends

\section{2 河道换水率的变化}

输水主干河道的换水率可在一定程度上反映调水对区域水动力的改善效果,换水率计算结果如图 5. 结 果表明:翻水站现状运行时 (方案 1、2), 卖鱼河换水率高达 $86 \%$, 北斗河换水率低至 $11 \%$,其余河道换水率 为 $31 \% \sim 41 \%$, 这与河道分流特征有关, 由于保丰碶闸关闭, 卖鱼河成为翠柏河主汉且河道短, 北斗河为支 汊, 来水大部分流人主汉使其换水率远高于支汉. 相比翻水站现状运行 (方案 2), 连续运行 (方案 3) 时北斗 河换水率 $(28 \%)$ ) 依然最小但略有增加, 其余河道换水率 (78\% 218\%) 显著提高, 这是因为来水量增加使主 汊换水率增大, 但来水难以到达的个别支汉换水率较低. 同样相比于方案 2 , 方案 4 中所有河道换水率 $(57 \% \sim 211 \%)$ 均明显提高, 北斗河换水率 $(83 \%)$ 相比于前 3 种方案增加效果显著, 这与引排水口分布有关, 东部新增 2 个排水口使区域引一排水路线增多, 水体之间的混掺作用增强, 换水率增大, 并且靠近排水口的 河道换水率较大.

\section{3 槽蓄量的变化}

分析河道槽蓄量在流域开发、航道清淤、防洪减灾及河道整治等方面有重要意义 ${ }^{[21]}$, 调水过程通常会改 变槽蓄量, 因此在增大内河径流量, 加快水体流动性的同时, 务必减少对槽蓄量的干扰, 以保证航运、防止漫 滩、达到水位低波动. 各方案下的槽蓄量变化情况如表 3, 引水范围及水量分布情况如图 6. 结果表明: 在不 开启沿江闸的工况下 (前 3 种方案), 河网区整体水位抬高, 槽蓄量变化值表现为: 方案 $1\left(1739 \mathrm{~m}^{3}\right)<$ 方案 2 $\left(6689 \mathrm{~m}^{3}\right)<$ 方案 $3\left(7109 \mathrm{~m}^{3}\right)$, 且前 3 种方案对槽蓄量的干扰较小, 增加率均在 $0.2 \%$ 左右, 其中方案 3 引水 服务范围较大, 方案 2 次之. 结合沿江闸联合调度时 (方案 4), 引水服务范围最大, 但整体水位下降幅度较 


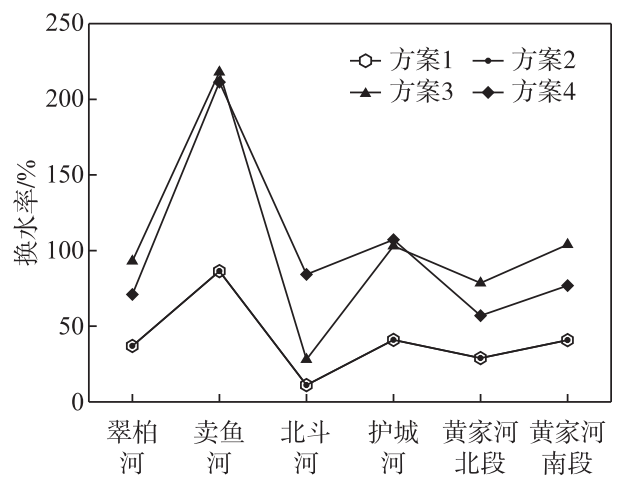

图 5 不同调水情况下的河道换水率

Fig.5 Water change rate of river under different water diversion schemes

大,槽蓄量下降率达 $6.4 \%$.

表 3 不同调水情况下的槽蓄量变化值

Tab.3 Variations of storage capacity under different water diversion schemes

\begin{tabular}{cccc}
\hline 方案 & 水位变化值 $/ \mathrm{cm}$ & 槽蓄量变化值 $/ \mathrm{m}^{3}$ & 槽蓄量变化率 $/ \%$ \\
\hline 1 & 0.38 & 1739 & 0.23 \\
2 & 0.40 & 6689 & 0.24 \\
3 & 0.43 & 7109 & 0.26 \\
4 & -10.50 & -176430 & -6.4 \\
\hline
\end{tabular}

\section{3 讨论}

\section{1 探讨最佳调水调控方案}

根据不同引调水工况下水量分配及水动力运行结果, 本研究中方案 4 的换水效果最佳,但槽蓄量变化 率最大, 前 3 种方案下的槽蓄量变化率较小且相差不大 $(0.23 \% \sim 0.26 \%)$. 相比于方案 2 , 方案 3 中输水主干 河道换水率的极差增大 2.5 倍, 达 $190 \%$, 局部换水率提高现象显著, 且引水服务范围与方案 2 相差不大, 故 综合水动力改善效果、槽蓄量变化以及投人产出率,方案 2 为当前引调水最优方案. 另外,引、排水闸门的闸 控方式决定了水动力明显改善的区域, 若考虑不同目标区域的水动力改善, 引、排水闸门以及内河节制闸不 同的闸控方案对管理更有价值,因此方案 1 4 分别对应不同区域水动力提高的工况.

\section{2 不同响应目标下调水引流工程改善平原河网水动力效果辨析}

平原河网地区在开展污染源治理的基础上,依靠调水引流工程激活水流、改善水动力成为水环境治理 的关键, 河道分流比与换水率是调水过程中两个主要的水动力条件指标, 在作为不同调水工况运行效果的 评价因子之外, 研究结果亦是推进了其他相关研究的开展, 分别以河道分流比、换水率为响应目标展开讨论. 3.2.1 以分流比为响应目标 分流比是河道的连通指标之一 ${ }^{[19]}$, 反映了河网区水系的连通性. 普遍存在个别 小支汉及断头河的分流比较小, 过水宽度大的支汉分流比较大的现象, 分流比相对较小的河道制约了水力 连通性. 在河道治理工程中, 对河道进行填埋、拓宽将会间接影响河道分流比, 从提升河网区水系连通性的 角度, 对相关河道进行拓宽疏浚, 以增加河道的过流能力, 同时结合区域调水引流工程, 利于河网区水力流 动性的提高. 另外, 在对河道进行整治而改变河床边界后, 上下游的物质能量传递发生改变, 河流通过自身 调整演变并遵循最小能耗率原理趋向于新的平衡状态 ${ }^{[22-23]}$. 从能量角度来看, 分流比一般表征河汉具有的 能量 ${ }^{[15]}$, 因此分流比的分析为进一步探究河流系统能量耗散规律奠定基础, 为分汉河道的治理提供科学 依据. 

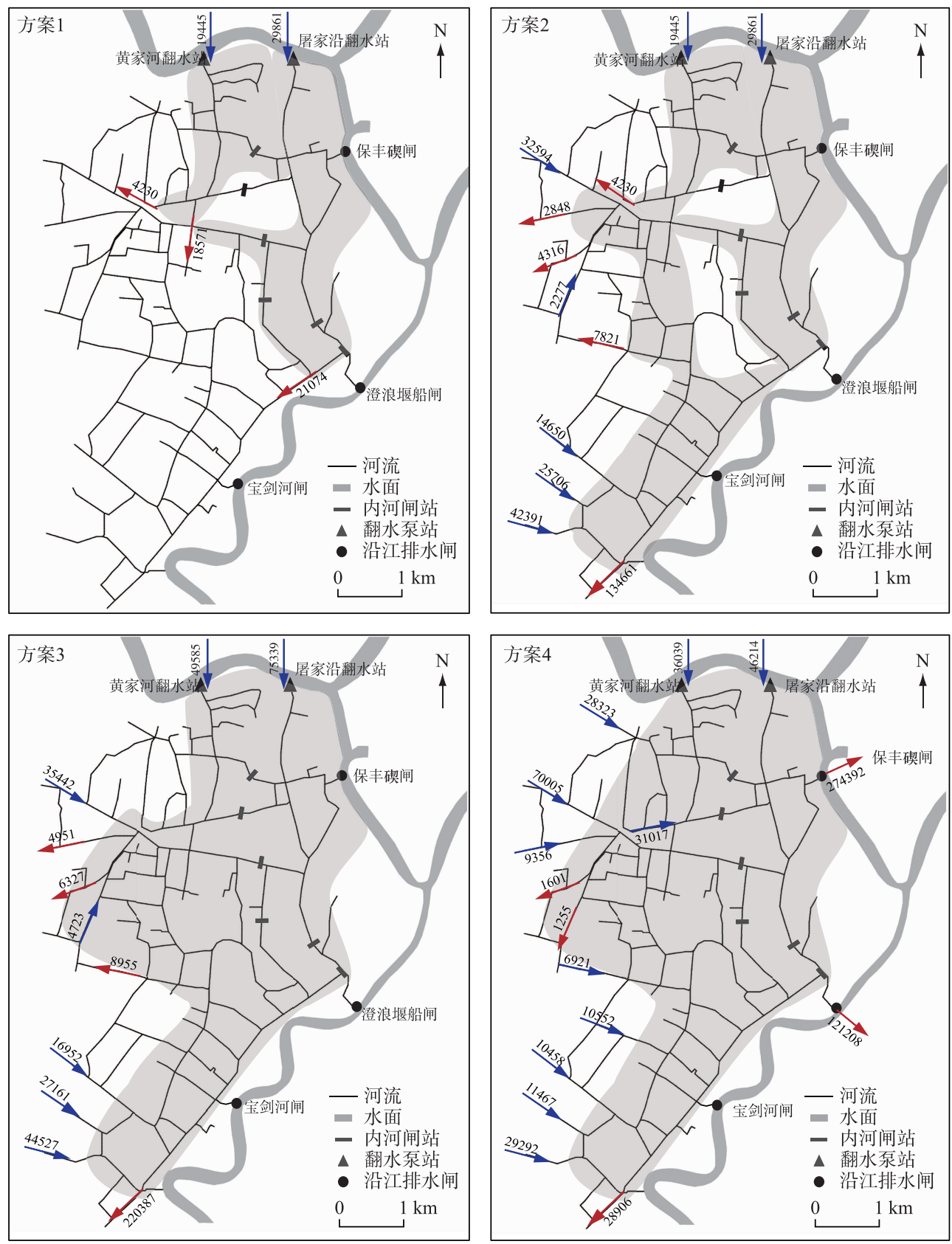

图 6 不同调水情况下的引水服务范围与水量 $\left(\mathrm{m}^{3}\right)$ 分布情况 (蓝色箭头代表进水;红色箭头代表出水)

Fig. 6 Water diversion service scope and water distribution under different water diversion schemes

(The blue arrow is for input, the red arrow is for output)

河道分流比亦反映了河道的输水能力, 河网概化原则便是以河道输水能力为依据, 对不同输水能力的 河道采取不同的概化方式以反映实际河网的水力特性. 野外原型同步监测结果为数值模拟中河网概化部分 作指导, 将输水主干河道以及分流比较大的河道作为单一河道参与模型计算; 分流比较小的小河道结合附 近河道进行合并, 海曙区输水主干河道主要为翠柏河、卖鱼河、北斗河、护城河、黄家河, 分流比较小的河道 
以断头河居多; 对于分流比接近零的小河道、小湖泊, 将其概化为调蓄水面, 区域内小规模的湖泊只有月湖. 由此得到的概化河网与天然河网输水能力以及水面率相近, 避免因次级河道资料不全而弱化河网概化密 度, 环境数值模型中河网概化密度是影响模拟精度的因素之一, 为合理确定河网概化密度, 缩小与自然状态 下河网结构的偏离, 对输水能力小的河道予以并联概化的同时, 尽量减小被概化河道的数量 ${ }^{[24]}$, 因此掌握河 道的输水能力对优化河网概化密度以进一步减小模拟偏差有参考意义.

3.2.2 以换水率为响应目标 在湖泊水体交换评估中, 通常以水龄来定量反映水体交换程度 ${ }^{[25]}$, 李一平 ${ }^{[25]}$ 通过水龄的时空分布研究 “引江济太”调水工程对太湖水动力的影响, 发现湖水交换存在时空非均质性. 在 平原河网的调水过程中也出现类似的规律,引排水口单一的调水工况下, 区域水动力改善效果不明显, 河道 水体循环程度不足; 仅增加单一引水口的来水量使部分河道流动性增强, 其中输水主干河道的流量剧增, 但 个别支汉过水量仍然偏小, 河网区存在一些 “死角” 区域, 其水动力改善效果甚微; 多个引、排水口联合调度 的工况下, 河网区水动力改善效果明显的区域受到引排水口位置的影响, 其中引水口与排水口距离较短的 区域,水动力改善效果显著,但同时制约了来水水流扩散的态势,引一排水路线短的格局削弱了来水活水的 作用,使调水服务范围缩小. 可见调水过程中平原河网区存在局部区域换水率提高的现象, 即换水率的空间 异质性, 这种差异主要与平原河网断头河的存在、引排水口分布以及引水流量密切相关, 因此在增加引水流 量的同时,引排水口的连线应尽可能贯通整个研究区域,该格局有助于整体换水率的提高而降低空间异质 性的影响.

河网区换水率低的河道可能成为水体富营养化风险比较大的区域,可基于换水率识别出河网区富营养 化高发区, 为区域水域健康情况提出预警, 对进一步探究平原河网水动力改善促进水环境质量提升提供基 础. 鉴于河网区换水率的空间异质性,断头河一般为引调水工程难以覆盖到的区域,易出现发黑发臭现 象 ${ }^{[20]}$, 可统筹局部与整体的关系, 推进断头河水环境治理研究的开展,利于特殊水动力特征河道治理和区域 水环境管控. 另外, 数值模拟中水动力模块是其他模块的基础, 野外监测数据及研究结果亦是为数值模拟提 供数据支撑.

\section{4 结论}

1) 平原河网水动力改善效果与引排水口分布、引水流量密切相关. 引水口与排水口距离短的格局对水 流扩散不能起到积极作用,为保证河网区水体交换良好,在增加引水流量的同时,引排水口的连线应尽可能 贯通整个区域.

2)平原河网水动力改善效果可通过河道换水率来反映,换水率具有空间异质性,这种差异主要与断头 河的存在、引排水口分布以及引水流量有关. 引调水工程能够改善分流能力大的支汊的水动力特征, 而对分 流能力小的支汉及断头河的水动力状况帮助不大.

3) 河网换水率提高、槽蓄量变化率减小是区域水动力改善的必要条件,故北部、西部引水与南部排水的 调水方式 (方案 2) 为当前引调水最优方案, 若考虑不同的局部区域水动力改善,引、排水闸门以及内河节制 闸不同的闸控方案对管理更有价值. 另外在引水时要保证人流水质优于受纳水体. 跟以往只用换水率评价 调水对区域水动力影响的做法相比,以槽蓄量变化率作为约束条件,使评价结果更合理.

4) 河道分流比反映河道的输水能力, 对优化河网概化密度以减小模拟偏差有参考意义,并为河流系统 能量耗散规律的研究奠定基础. 基于换水率可识别出河网区富营养化高发区, 为进一步探究平原河网水动 力改善促进水环境质量提升提供基础.

\section{5 参考文献}

[ 1 ] Wei YY, Li YP, Weng SL et al. Impact of urbanization on stream structure and connectivity of plain river network in the Taihu Basin. J Lake Sci, 2020, 32(2) : 553-563. DOI: 10.18307/2020.0223. [魏菳菳, 李一平, 翁晍琳等. 太湖流域 城市化对平原河网水系结构与连通性影响. 湖泊科学, 2020,32(2) : 553-563.]

[ 2 ] Lai GY, Wang P, Huang XL et al. A simulation research of impacts of the Lake Poyang hydraulic project on hydrology and hydrodynamics. J Lake Sci , 2015, 27 (1) : 128-140. DOI: 10.18307/2015.0116. [赖格英, 王鹏, 黄小兰等. 鄱阳湖水 利枢纽工程对鄱阳湖水文水动力影响的模拟. 湖泊科学, 2015, 27(1) : 128-140.] 
[ 3 ] Tang JZ, Song T, Jiang XY et al. International experiences for river pollution control. World Regional Studies, 1998, (2) : 114-119. [汤建中, 宋韬, 江心英等. 城市河流污染治理的国际经验. 世界地理研究, 1998, (2) : 114-119.]

[ 4 ] Bode H, Evers P, Albrecht DR. Integrated water resources management in the Ruhr River Basin, Germany. Water Science and Technology, 2003, 47(7/8): 81-86. DOI: 10.2166/wst.2003.0674.

[ 5 ] Xiong HB, Chen X, Zhang SS. Method of improving the water quality of polluted rivers based on the MIKE11 model. Environmental Science, 2017, 38 (12) : 5063-5073. DOI: 10.13227/j. hjkx. 201703257. [ 熊鸿斌, 陈雪, 张斯思. 基于 MIKE11 模型提高污染河流水质改善效果的方法. 环境科学, 2017, 38(12): 5063-5073.]

[ 6 ] Huang CL, Li X, Sun YY. Water age distribution of the Lake Taihu and impact of the Yangtze River to Lake Taihu Water Transfer Project on the water age. J Lake Sci, 2017, 29(1) : 22-31. DOI: 10.18307/2017.0103. [黄春琳, 李熙, 孙永 远. 太湖水龄分布特征及“引江济太”工程对其的影响. 湖泊科学, 2017, 29(1) : 22-31.]

[ 7 ] Jia HF, Yang C, Zhang YH et al. Simulations of a water quality improvement for urban river networks. Journal of Tsinghua University: Science and Technology, 2013, 53(5): 665-672, 728. [贾海峰, 杨聪, 张玉虎等. 城镇河网水环境模拟及 水质改善情景方案. 清华大学学报:自然科学版, 2013, 53(5): 665-672, 728.]

[ 8 ] Song LX, Yang F, Hu XZ et al. A coupled mathematical model for two-dimensional flow-transport simulation in tidal river network. Advances in Water Science, 2014, 25(4) : 550-559. [ 宋利祥, 杨芳, 胡晓张等. 感潮河网二维水流-输运耦 合数学模型. 水科学进展, 2014, 25(4): 550-559.]

[ 9 ] Tian CC, Wei J, Huang DJ. Study on the scale of water diversion of plain river network in the main urban area of Wenzhou City based on the hydrodynamic and water quality united-control model. Water Resources and Power, 2019, 37(4) : 44-47. [田传冲, 魏婧, 黄冬菁. 基于水动力水质联合调控的温州市主城区平原河网引水规模研究. 水电能源科学, 2019, 37(4): 44-47.]

[10] Wang HJ, Zhang JY, Wang XZ et al. Research and application of flow calculation model based on average flow velocity distribution of cross section vertical line. Journal of China Hydrology, 2019, 39(5): 50-54. [王鸿杰, 张建云, 王兴泽 等. 基于横断面垂线平均流速分布的流量计算模型研究与应用. 水文, 2019, 39(5): 50-54.]

[11] Li CJ. Formula derivation of minimum water depth of flow measurement with current-meter method. Journal of China Hydrology, 2010, 30(2) : 76-79. [李长江. 流速仪法测流最小水深计算公式推导. 水文, 2010, 30(2) : 76-79.]

[12] Han JW, Niu RP, Wang Y et al. Research on flow calculation of virtual vertical velocity time difference method. Journal of China Hydrology, 2020, 40 (1) : 52-57. [韩继伟, 牛睿平, 王岩等. 虚拟垂线流速时差法流量计算方法研究. 水文, $2020,40(1): 52-57$.

[13] Sun ZH, Li Q, Yan X et al. Analysis of the critical relationship between the water levels of Dongting Lake and Chenglingji station. Advances in Water Science, 2017, 28(4): 496-506. [孙昭华, 李奇, 严金等. 洞庭湖区与城陵矶水位关联性 的临界特征分析. 水科学进展, 2017, 28(4) : 496-506.]

[14] Geberemariam TK. Numerical analysis of stormwater flow conditions and separation zone at open-channel junctions. Journal of Irrigation and Drainage Engineering, 2017, 143(1) : 05016009. DOI: 10.1061/(asce) ir.1943-4774.0001114.

[15] Liu XF, Huang HQ, Deng CY. A theoretical investigation of the hydrodynamic conditions for equilibrium island morphology in anabranching rivers. Advances in Water Science, 2014, 25(4) : 477-483. [刘晓芳, 黄河清, 邓彩云. 江心洲平衡 形态水动力条件的理论分析. 水科学进展, 2014, 25(4): 477-483.]

[16] Li YP, Acharya K, Yu ZB. Modeling impacts of Yangtze River water transfer on water ages in Lake Taihu, China. Ecological Engineering, 2011, 37(2): 325-334. DOI: 10.1016/j.ecoleng.2010.11.024.

[17] Liao XH, Zhu F, Li XC et al. Research on the channel storage characteristic of the Dongting Lake based on typical year flood. China Rural Water and Hydropower, 2018, (5): 134-137, 143. [廖小红, 朱枫, 黎昔春等. 典型年洪水的洞庭 湖槽蓄特性研究. 中国农村水利水电, 2018, (5) : 134-137, 143.]

[18] Li JB, He X, Yang B et al. Temporal evolution of dried up days and the influencing mechanisms at three outlets along Jingjiang in the middle reach of Yangtze River. Journal of Natural Resources, 2016, 31 ( 10 ) : 1713-1725. DOI: 10. 11849/zrzyxb.20151021. [李景保, 何霞, 杨波等. 长江中游荆南三口断流时间演变特征及其影响机制. 自然资源 学报, 2016, 31(10): 1713-1725.]

[19] Wang ZY, Li YP, Dong ZQ et al. Influencing factors of flow diversion ratio in plain river networks of Taihu Lake Basin. Water Resources Protection, 2019, 35(4): 49-54, 75. [王子悦, 李一平, 董志强等. 太湖流域平原河网分流比影响 因素. 水资源保护, 2019, 35(4): 49-54, 75.] 
[20] Wen S, Wang Q, Li YM et al. Remote sensing identification of urban black-odor water bodies based on high-resolution images: A case study in Nanjing. Environmental Science, 2018, 39(1) : 57-67. DOI: 10.13227/j.hjkx.201703264. [温爽, 王桥, 李云梅等. 基于高分影像的城市黑臭水体遥感识别: 以南京为例. 环境科学, 2018, 39(1) : 57-67.]

[21] Wang W, Ye M, Liu JB. Functional design and realization of calculation modules of channel storage. Yangtze River, 2014, 45(2): 66-70. [王伟，叶敏，刘静波. 河道槽蓄量计算模块功能设计与实现. 人民长江, 2014, 45(2): 66-70.]

[22] Xu GB, Zhao LN. Analysis of channel pattern changes in the lower Yellow River based on the rate of energy dissipation. Journal of Hydraulic Engineering, 2013, 44(5): 622-626. [徐国宾, 赵丽娜. 基于能耗率的黄河下游河型变化趋势 分析. 水利学报, 2013, 44(5): 622-626.]

[23] Yu HZ, Li LJ, Li JY. Evaluation of water resources carrying capacity in the Beijing-Tianjin-Hebei Region based on quantity-quality-water bodies-flow. Resources Science, 2020, 42(2) : 358-371. DOI: 10.18402/resci.2020.02.14. [余影哲, 李 丽娟, 李九一. 基于量-质-域-流的京津冀水资源承载力综合评价. 资源科学, 2020, 42(2) : 358-371.]

[24] Yang L, Pang Y. Revised method of water quality at the controlled section in Tiaoxi Basin. Water Resources and Power, 2017, 35(1) : 43-47. [杨柳, 逢勇. 苕溪流域控制断面河网概化水质订正方法. 水电能源科学, 2017, 35(1): 43-47.]

[25] Li YP, Tang CY, Wang C et al. Improved Yangtze River Diversions: Are they helping to solve algal bloom problems in Lake Taihu, China? Ecological Engineering, 2013, 51: 104-116. DOI: 10.1016/j.ecoleng.2012.12.077. 